\title{
Inclusion of Civic Education in Social Studies Subject at Primary Level in AJK: A Perspective Study
}

\author{
* Arshad Mahmood Arshad, PhD Scholar \\ ** Dr. Khushbakht Hina, Assistant Professor \\ *** Tariq Mahmood Tariq, PhD Scholar
}

\begin{abstract}
The main objective of the study was to investigate the perceptions of social studies teachers about the execution of civic education in government girls and boys schools at the primary level in Azad Jammu \& Kashmir. The present study was quantitative and the survey was used as the research design. 102 teachers of social studies of grade $4^{\text {th }}$ and $5^{\text {th }}$ from girls/boys primary schools of district Muzaffarabad, Mirpur, and Poonch AJK was the target population. The sample size was determined by using a stratified proportionate sampling technique and the sample size was calculated by online Raosoft sample size determining formula. Thus the sample size was 46. In the present study, a questionnaire was used as a research tool, and a questionnaire was developed based on a national curriculum document for social studies grade $4^{\text {th }}$ and $5^{\text {th }}$ will be used to investigate perceptions of social studies teachers. To validate items of the questionnaire, these were reviewed twice, once by a panel of experts in education and statistics. Ambiguous items and statements were omitted. The reliability of the questionnaire was to find out through Cronbach Alpha. Its value was found at 0.85. For data collection, a questionnaire was administered to the sampled social studies teachers of grades $4^{\text {th }}$ and $5^{\text {th }}$ of District Muzaffarabad, Mirpur, and Poonch Azad Jammu \& Kashmir by the researcher personally. Quantitative data analysis was performed by using Statistical Packages for the Social Sciences (SPSS). And results were presented in the form of destructive, inferential statistics.

Keywords: Perceptions, Execution, Civic Education, Social Studies Subject, Primary Level Introduction

Education related to civic sensibility is very necessary for the development of a sense of responsibility, self-discipline, respect, peace, freedom of speech, tolerance, and civility (Husain, 2007). Its concept includes both types of training that are formal training and informal for the inculcation of civility among the citizens to make them effective and useful citizens of the country (Finkal, 2000). Furthermore, the concept of civic education explains that individuals should be developed in such a way they become civilized citizens at local and international level (Kezban, 2014). Thus the importance of developing students in this area is very important. If schools fail in developing students as sensible and responsible citizens, it may hurt local as well as a global society. However, it is an issue is that some of the countries like Pakistan do not give much importance to civic education. Appropriate teaching activities are not practiced in the classroom by teachers for civic education. As a result of which sensible and responsible students are not developed. Likewise, traditional teaching approaches cannot meet the requisite needs of civic education. Teachers should be well versed with the modern teaching methods for teaching civic education, to prepare the new generation, according to the future needs of the societies (Dean \& Smith, 2002).

There is no separate textbook for civic education in Pakistan. It is included in the textbook of social studies. Civic related education is given to students at the primary level, especially in $4^{\text {th }}$ and $5^{\text {th }}$ grade. In Pakistani schools, great stress is placed on science and technology and little emphasis is given to social studies and thus to civic education which is a part of social studies. Little time is allocated on the timetable for social studies / civic education in comparison to science and math.
\end{abstract}

\footnotetext{
* National University of Modern Languages Islamabad Email: Arshad.hrd@gmail.com

** National University of Modern Languages Islamabad Email: kbhina@numl.edu.pk

***National University of Modern Languages Islamabad Email: tmtariq.education@gmail.com
} 
Furthermore, there is a general belief among teachers that social studies do not require conceptual understanding therefore it can be learned by rote and anyone can teach it (Dean, 2005).

The education having a special focus on civic sense and citizenship helps students to recognize their rights and enjoy freedom. It teaches them to give importance to the freedom of others as well. Civic education enables students to respect the rule of law and problem solving (Branson, 1998). The aim of civic education is developing the students as polite, active, responsible, productive, and participative to life to its fullest citizens. The education system of any country is also responsible for all the above-mentioned qualities in the students who recognize the importance of the constitution of Pakistan, the value of democracy, human rights, problem-solving of the country, participation growth of the society and country. Thus providing civic to students becomes important. For the achievement of the said goal, usually, the education department of the country develops a curriculum of civic education, prepares textbooks, and trains teachers. Sometimes separate textbook for civic education is not prepared. It is included in the textbook of social studies. Therefore, a need is felt to investigate the perceptions of teachers regarding civic education in social studies subjects at the primary level in AJK, as well as to find out the perceptions of social studies teachers about the execution of civic education and to review and explore the content of social studies textbook prescribed by Azad Jammu \& Kashmir textbook board in relation with National Curriculum Document at primary level in Azad Jammu \& Kashmir.

\section{Literature Review}

Civic education can be described as the education having a focus on developing students' concepts related to rights, responsibilities, duties, positivity, acceptable behaviors, and democracy (Smith, Fountain \& McLean, 2003). The methods, through which learners improve, development of cognition and conceptualization of civic education, and also affective-behavioral dispositions to civic education, can or may depend on numerous factors in addition to their school ecology (Wade \& Saxe, 2017).

Civic, Peace, and Tolerance Education targets learning the skills, for example, aptitudes, information, and attitudes, required to be a functioning, responsible, and critical citizen. Its definitive objective is to instruct the people on citizenship and make them aware of their rights and responsibilities. It includes the whole society and starts at home when parents start instructing young children about do's and don'ts'. In the educational set up the active learning strategies, debates, discussions, and cocurricular activities are a way forward to Civic, Peace, and Tolerance Education (Klopper, 2019).

The conception of civic education places the central main emphasis on every student who is affected by factors of socialization in diverse school ecology. It shows that learning about civic education is not restricted to the teaching and learning process at school but is the result of many procedures taken place in the environment outside of school. Civic education can also be called selfgovernance. It means that the individuals of society have a sense of good and bad. They do not accept the orders of the government and other people. They see the orders in their context. They will analyze it and then accept or reject it and raise their voice for review or improvement (Kahne \& Westhemer, 2015).

Civic Education also means that how the government of a country works in an organized and systematic way. Civic education protects the rights, responsibilities, and duties of persons of any society. So, no democratic objective can be attained without the participation of citizens in civic education. Rule of law and good governance are mainly focused on civic education (Finkel, 2002). So that contributes to societal activities in a civil manner, citizens need to have the prerequisite knowledge, skills, attitudes, and values (Jalbert, 2016). Civic education is a basic factor of the process of social and human development, which is the base of civilization (Harder, 2018).

The civilization described by Goupil and Pallascio (1998) was not restricted to social development alone; rather it was describing the transition from traditional to advancement in terms of capability building, infrastructure, and contributions of individuals to the growth of the nation. The role of civic education in any democratic nation is in many ways, as history has consistently recapitulated the need for the incorporation of civic education into the leadership process. Over the past few years, nations have constantly been faced with several challenges and issues that threaten our weak democracy and some of these have been attributed to political intolerance, lop-sidedness, suppression of political opponent, and quieting of the people. These all factors have been associated with a poor understanding of civic education and the less participation of citizens who can provide and sustain quality democracy. 
Smith, Nowacek, and Bernstein (2010) explained civic education as an element of education that makes the society to function well, to make a better situation of law and order, and provide an authoritative mandate for law, social harmony, and peaceful cohabitation of individuals. The United Nations Development Programme (UNDP, 2004) defines civic education as learning, which enables an individual to effectively participate in the developmental process of society and democracy. They dimensionalized civic education into citizen education, and education for collective life. Smith et al. (2003) regarded it as democratic education that considers all aspects of human rights, which emphasizes the need for rule of law and good governance (Rios, Bennion \& Simpson, 2013). Civic Education can additionally include any type of systematic process that is helpful to organize people politically, for example, through public interest or reform groups or trade or professional association (Kuh, 2008). Civic education can also be described as a learning system including the principles of civic life for example respect for law and order, being responsible, critical thinking or reasoning, independence, collaboration and cooperation in activities, accepting the principles of the political system of the country, the organization of the political system and many other related subjects and components (Finley \& McNair, 2013). Civic education can also be regarded as the instruction given to citizens on how to contribute civically; especially within the borders of national and universal citizenship. Therefore, it will be inclusively correct to state that Civic Education fundamentally addresses the rights, responsibilities, and duties of citizens to the people and the government. In a broader sense, civic education encompasses all the processes which have an impact on individuals' belief system, promises, abilities, actions, reactions as the part of society. Civic education is the preparation of productive and responsible citizens (Calderón, 2007).

Habermas (1972) explains that the latest concept of civic education is to develop responsible and productive citizens. He also describes, "Dominant views of Citizenship Education thus, the civic republicanism (responsibilities-based) and the liberal (rights-based) seem to offer varied understandings about what it means to educate for citizenship". In short, civic education is very important for attaining the real objectives of education.

The education given to members of the society during the pre-colonial period prepared them to take certain roles in society and to become useful members of that society (Caro \& Schulz, 2012). Therefore, the main objective of this education was to train youths for adulthood. Learning by doing or apprenticeship was the method that Africans had always used. Apart from skills development, African education emphasized social responsibility, political participation, spirituality, and moral values. This was passed on from one generation to the next by word of mouth through song, dance, proverbs, folktales, and myths. This resulted in cultural estrangement, which in turn served to reinforce Africans' self-devaluation and self-hatred (Brodie, 2004).

\section{Objective of the Study}

The main objective of the study was to investigate the perceptions of social studies teachers about the execution of civic education in government girls and boys schools at the primary level in Azad Jammu \& Kashmir.

\section{Research Methodology}

The present study was quantitative and the survey was used as the research design.

\section{Research Population}

102 teachers of social studies of grade $4^{\text {th }}$ and $5^{\text {th }}$ from girls/boys primary schools of district Muzaffarabad, Mirpur, and Poonch AJK was the target population.

\section{Sampling Procedure}

The sample size was determined by using a stratified proportionate sampling technique and the sample size was calculated by online Raosoft sample size determining formula. Thus the sample size will be 46 .

\section{Instrument of the Study}

In the present study, a questionnaire was used as a research tool, and a questionnaire was developed based on a national curriculum document for social studies grade $4^{\text {th }}$ and $5^{\text {th }}$ will be used to investigate perceptions of social studies teachers. To validate items of the questionnaire, these were reviewed twice, once by a panel of experts in education and statistics. Ambiguous items and statements were omitted. The reliability of the questionnaire was to find out through Cronbach Alpha. Its value was found at 0.85 . 


\section{Data Collection}

For data collection, a questionnaire was administered to the sampled social studies teachers of grades $4^{\text {th }}$ and $5^{\text {th }}$ of District Muzaffarabad, Mirpur, and Poonch Azad Jammu \& Kashmir by the researcher personally.

\section{Data Analysis}

Quantitative data analysis was performed by using Statistical Packages for the Social Sciences (SPSS). And results were presented in the form of destructive, inferential statistics.

\section{Results}

Table 1 Civic Sensibility and Citizenship

\begin{tabular}{|c|c|c|c|c|c|c|c|}
\hline Statements & & SA & A & $\mathrm{N}$ & $\mathrm{D}$ & $\mathrm{SD}$ & Mean \\
\hline \multirow[t]{2}{*}{ Citizen and Global Citizen } & f & 6 & 24 & 2 & 3 & 3 & \multirow{2}{*}{2.29} \\
\hline & $\%$ & 15.8 & 63.2 & 5.3 & 7.9 & 7.9 & \\
\hline \multirow[t]{2}{*}{ Human Rights } & $\mathrm{f}$ & 9 & 12 & 5 & 7 & 5 & \multirow{2}{*}{2.66} \\
\hline & $\%$ & 23.1 & 31.6 & 13.2 & 18.4 & 13.2 & \\
\hline \multirow[t]{2}{*}{ Diversity } & $\mathrm{f}$ & 6 & 15 & 7 & 5 & 5 & \multirow{2}{*}{2.68} \\
\hline & $\%$ & 15.8 & 38.5 & 18.4 & 13.2 & 13.2 & \\
\hline \multirow[t]{2}{*}{ Equal Rights } & $\mathrm{f}$ & 6 & 19 & 6 & 3 & 4 & \multirow{2}{*}{2.47} \\
\hline & $\%$ & 15.8 & 50.0 & 15.8 & 7.9 & 10.5 & \\
\hline \multirow[t]{2}{*}{ Harmony } & f & 20 & 3 & 9 & 3 & 3 & \multirow{2}{*}{2.11} \\
\hline & $\%$ & 52.6 & 7.9 & 23.7 & 7.9 & 7.9 & \\
\hline \multirow[t]{2}{*}{ Household and Neighborhood } & $\mathrm{f}$ & 20 & 7 & 7 & 2 & 2 & \multirow{2}{*}{1.92} \\
\hline & $\%$ & 52.6 & 18.4 & 18.4 & 5.3 & 5.3 & \\
\hline \multirow[t]{2}{*}{ Peace and Conflict } & $\mathrm{f}$ & 23 & 9 & 3 & 1 & 2 & \multirow{2}{*}{1.68} \\
\hline & $\%$ & 60.5 & 23.7 & 7.9 & 2.6 & 5.3 & \\
\hline \multirow{2}{*}{$\begin{array}{l}\text { Discussion and Negotiation as the tools for } \\
\text { resolving conflicts }\end{array}$} & $\mathrm{f}$ & 19 & 7 & 4 & 5 & 3 & \multirow{2}{*}{2.11} \\
\hline & $\%$ & 50.0 & 18.4 & 10.5 & 13.2 & 7.9 & \\
\hline \multirow[t]{2}{*}{ Traffic rules and keep the environment clean } & f & 9 & 12 & 8 & 7 & 2 & \multirow{2}{*}{2.63} \\
\hline & $\%$ & 23.7 & 31.6 & 21.1 & 18.4 & 5.3 & \\
\hline \multirow{4}{*}{$\begin{array}{l}\text { Good manners like be polite, show respect to } \\
\text { others, be helpful to others } \\
\text { Qualities of good citizens on notebooks about } \\
\text { good citizens are responsible }\end{array}$} & $\mathrm{f}$ & 25 & 4 & 7 & 1 & 1 & \multirow{2}{*}{1.66} \\
\hline & $\%$ & 65.8 & 10.5 & 18.4 & 2.6 & 2.6 & \\
\hline & f & 11 & 17 & 6 & 3 & 1 & \multirow{2}{*}{2.11} \\
\hline & $\%$ & 28.9 & 44.7 & 15.8 & 7.9 & 2.6 & \\
\hline
\end{tabular}

Table 1 depicts that $79 \%$ agreed with the statement that citizen and global citizen. $5 \%$ given no response while $16 \%$ disagreed. Thus, it is concluded that most of the respondents agreed that citizen and global citizen. 56\% agreed with the statement that human rights. $13 \%$ given no response while $32 \%$ disagreed. Thus, it is concluded that most of the respondents agreed that human rights. $55 \%$ agreed with the statement that diversity. $18 \%$ given no response while $26 \%$ disagreed. Thus, it is concluded that most of the respondents agreed that diversity. $65 \%$ agreed with the statement that equal rights. $16 \%$ given no response while $19 \%$ disagreed. Thus, it is concluded that most of the respondents agreed that equal rights. $63 \%$ agreed with the statement that harmony. $24 \%$ given no response while $16 \%$ disagreed. Thus, it is concluded that most of the respondents agreed that harmony. $71 \%$ agreed with the statement that household and neighborhood. $11 \%$ given no response while $18 \%$ disagreed. Thus, it is concluded that most of the respondents agreed that household and neighborhood. $85 \%$ agreed with the statement that peace and conflict. $10 \%$ given no response while $5 \%$ disagreed. Thus, it is concluded that most of the respondents agreed that peace and conflict. 68\% agreed with the statement that discussion and negotiation as the tools for resolving conflicts. 5\% given no response while $21 \%$ disagreed. Thus, it is concluded that most of the respondents agreed that discussion and negotiation as the tools for resolving conflicts. 56\% agreed with the statement that traffic rules and keep the environment clean. $21 \%$ given no response while $24 \%$ disagreed. Thus, it is concluded that most of the respondents agreed that traffic rules and keep the environment clean. 77\% agreed with the statement that good manners like be polite, show respect to others, be helpful to others. $18 \%$ given no response while 5\% disagreed. Thus, it is concluded that most of the respondents agreed that good manners like be polite, show respect to others, be helpful to others. And $76 \%$ agreed with the statement that qualities of good citizens on notebooks about good citizens are responsible. 
$16 \%$ given no response while $11 \%$ disagreed. Thus, it is concluded that most of the respondents agreed that the qualities of good citizens on notebooks about good citizens are responsible.

Table 2 Democratic Awareness

\begin{tabular}{|c|c|c|c|c|c|c|c|}
\hline Statements & & SA & A & $\mathrm{N}$ & $\mathrm{D}$ & SD & Mean \\
\hline \multirow[t]{2}{*}{ Promote democratic practices } & $\mathrm{f}$ & 15 & 14 & 3 & 2 & 4 & \multirow{2}{*}{2.11} \\
\hline & $\%$ & 39.5 & 36.8 & 7.9 & 5.3 & 10.5 & \\
\hline \multirow{2}{*}{$\begin{array}{l}\text { Freedom of speech to every student without any } \\
\text { discrimination }\end{array}$} & $\mathrm{f}$ & 8 & 15 & 10 & 4 & 1 & \multirow{2}{*}{2.34} \\
\hline & $\%$ & 21.1 & 39.5 & 26.3 & 10.5 & 2.6 & \\
\hline \multirow[t]{2}{*}{ Treat every student equally } & $\mathrm{f}$ & 6 & 20 & 4 & 5 & 3 & \multirow{2}{*}{2.44} \\
\hline & $\%$ & 15.8 & 52.6 & 10.5 & 13.2 & 7.9 & \\
\hline \multirow[t]{2}{*}{ Develop sense of accountability } & f & 9 & 16 & 4 & 5 & 4 & \multirow{2}{*}{2.31} \\
\hline & $\%$ & 23.7 & 42.1 & 10.5 & 13.2 & 10.5 & \\
\hline \multirow[t]{2}{*}{ Ensure trenchancy } & f & 21 & 3 & 7 & 3 & & \multirow{2}{*}{2.10} \\
\hline & $\%$ & 55.3 & 7.9 & 18.4 & 7.9 & 10.5 & \\
\hline \multirow[t]{2}{*}{ Democratic way of selection } & $\mathrm{f}$ & 18 & 5 & 8 & 4 & 3 & \multirow{2}{*}{3.31} \\
\hline & $\%$ & 44.7 & 13.2 & 21.1 & 10.5 & 7.9 & \\
\hline
\end{tabular}

Table 2 shows that $67 \%$ agreed with the statement that promotes democratic practices. $8 \%$ given no response while $16 \%$ disagreed. Thus, it is concluded that most of the respondents agreed that promote democratic practices. $61 \%$ agreed with the statement that freedom of speech to every student without any discrimination. $26 \%$ given no response while $13 \%$ disagreed. Thus, it is concluded that most of the respondents agreed that freedom of speech to every student without any discrimination. $68 \%$ agreed with the statement that treats every student equally. $11 \%$ given no response while $21 \%$ disagreed. Thus, it is concluded that most of the respondents agreed that treat every student equally. $66 \%$ agreed with the statement that treats develop a sense of accountability. $10 \%$ given no response while $24 \%$ disagreed. Thus, it is concluded that most of the respondents agreed that develop a sense of accountability. $62 \%$ agreed with the statement that ensures trenchancy. $18 \%$ given no response while $20 \%$ disagreed. Thus, it is concluded that most of the respondents agreed that ensure trenchancy. And $58 \%$ agreed with the statement that ensures trenchancy. $21 \%$ given no response while $22 \%$ disagreed. Thus, it is concluded that most of the respondents agreed that ensure trenchancy.

\section{Conclusions and Discussion}

This study presents the concept of civic education at the primary level in AJ\&K. For example, to promote democratic practices, Freedom of speech to every student without any discrimination, Treat every student equally, develop a sense of accountability, ensure trenchancy and democratic way of selection. But, these concepts of civic education is missing in most of the courses in pre-service teacher education. It is concluded that most of the respondents agreed that citizen and global citizen, human rights, diversity, equal rights, harmony, household and neighborhood, peace and conflict, discussion and negotiation as the tools for resolving conflicts, traffic rules, and keep the environment clean, good manners like be polite, show respect to others, be helpful to others and qualities of good citizens on notebooks about good citizens are responsible. This civil role of a teacher of their capacity to influence students' conception of citizenship through their preconceived notions of citizenship and their subsequent influence by way of curricula design (Westheimer \& Kahne, 2004; Marri et al, 2014). This study suggested teacher candidates are aware of this influence on their students' conceptions of citizenship. It is founded that the majority of the respondents agreed that promote democratic practices, freedom of speech to every student without any discrimination, treat every student equally, develop a sense of accountability and ensure trenchancy and ensure trenchancy. A study by Stambler (2011) found that teacher candidate educational courses can prepare teachers for the need of embedding civic engagement as a paramount priority in our future education. We found a great similarity in the result of this study and Clayton's (2005) and Lee's (2004) studies in terms of concern on emphasizing teachers' own civic and citizenship in the classes. Once the educational community accepts that we must revaluate our teacher candidate education to prioritize the why of education versus the how, i.e. the purpose of social studies education versus a narrow focus on teaching pedagogical practices, our society can make real progress in all aspects of our democratic society because democracy flourishes as a result of a well-educated and engaged citizenry.

\section{Recommendations}


The study recommends that teachers may be developed in Civic education, more participatory methodologies may be employed in its teaching, reality definers may take a firm position that allows divergent views and political tolerance discourse, and that all students passing through the primary level are subjected to the Civic Education course. The national curriculum of Pakistan may be revised in prospective teacher education curriculum to point out civic education.

\section{References}

Ahghar, G., \& Eftekhari, A. (2016). The Content Analysis of Social Sciences Studies' Textbook of the Eighth Grade (the First Grade of High School) Based on the Components of Citizenship Education. European Online Journal of Natural and Social Sciences: Proceedings, $5(3$ (s), pp-315.

Ainley, J., Schulz, W., \& Friedman, T. (2013). ICCS 2009 encyclopedia: Approaches to civic and citizenship education around the world.

Association of American Colleges, \& National Leadership Council (US). (2007). College learning for the new global century: A report from the National Leadership Council for Liberal Education \& America's Promise. Assn of Amer Colleges.

Brodie, J. (2004). Introduction: globalization and citizenship beyond the nation-state. Citizenship Studies, 8(4), 323-332.

Bronfenbrenner, U. (2005). Making human beings human: Bioecological perspectives on human development. Sage.

Calder, J. Z. (2007). Race, poverty, and social justice: Multidisciplinary perspectives through service learning. Stylus Publishing, LLC.

Caro, D. H., \& Schulz, W. (2012). Ten hypotheses about tolerance toward minorities among Latin American adolescents. Citizenship, Social and Economic Education, 11(3), 213- 234.

Carrera, S. (2005). What does free movement mean in theory and practice in an enlarged EU? European law journal, 11(6), 699-721.

Dean, B. L. (2005). Citizenship education in Pakistani schools: Problems and possibilities. International Journal of Citizenship and Teacher Education, 1(2), 35.

Delanty, G., \& Rumford, C. (2005). Rethinking Europe: Social theory and the implications of Europeanization. Routledge.

Diamond, L. (2015). Facing up to the democratic recession. Journal of Democracy, 26(1), 141-155.

Dibaba, F. B. (2017). The Role of Civics and Ethical Education in Shaping Attitudes of Students: The Case of Jimma College of Teachers Education. Global Journal of Human-Social Science Research.

Eckstein, K., Noack, P., \& Gniewosz, B. (2013). Predictors of intentions to participate in politics and actual political behaviors in young adulthood. International Journal of Behavioral Development, 37(5), 428-435.

Finley, A., \& McNair, T. (2013). Assessing Underserved Students' Engagement in High- Impact Practices. With an Assessing Equity in High-Impact Practices Toolkit. Association of American Colleges and Universities.

Fullan, M., \& Steigelbauer, S. M. (1991). The new meaning of educational change. Toronto/New York, NY: Ontario Institute for Studies in Education.

Gardner, H. (2011). Frames of mind: The theory of multiple intelligences. Hachette UK.

Gattullo, F. (2000). Formative assessment in ELT primary (elementary) classrooms: an Italian case study. Language Testing, 17(2), 278-288.

Gholtash, A., Taheri, A., \& Marahel, F. (2014). Educational democracy and its effects on students' critical thinking and social skills in middle school.

Ghosh, S. (2015). Learning from the community: Agenda for citizenship education. Education, Citizenship, and Social Justice, 10(1), 21-36.

Harder, A. (2018). Beyond conventional civic participation, beyond the moral-political divide: Young people and contemporary debates about citizenship. Journal of Moral Education, 35(4), 473493.

Jalbert, J. G. (2016). The civic attitudes of ethnic minority youth and the impact of citizenship education. Journal of Ethnic and Migration Studies, 34(1), 27-54.

Kerr, D., McCarthy, S., \& Smith, A. (2002). Citizenship Education in England, Ireland, and Northern Ireland. European journal of education, 37(2), 179-191. 
Klopper, C. (2019). The role of parents in educating their young children as democratic citizens (Doctoral dissertation, University of Pretoria).

Kuh, G. D. (2008). Excerpt from high-impact educational practices: What they are, who has access to them, and why they matter. Association of American Colleges and Universities.

Mahmoudi, M. T. (2011). Content Analysis of the textbooks of social education curriculum from the perspective of citizenship education approach. Research in Curriculum, 9(2), 28- 29.

McCartney, A. R. M., Bennion, E. A., \& Simpson, D. W. (Eds.). (2013). teaching civic engagement: From student to active citizen. American Political Science Association.

Rotberg, R. I. (Ed.). (2004). State failure and state weakness in a time of terror. Brookings Institution Press.

Shami, P. A., \& Hussain, K. S. (2006). Development of education in Pakistan. Academy of Educational Planning and Management, Ministry of Education.

Thapa, A., Cohen, J., Guffey, S., \& Higgins-D’Alessandro, A. (2013). A review of school climate research. Review of educational research, 83(3), 357-385.

Wade, R. C., \& Saxe, D. W. (1996). Community service-learning in social studies: Historical roots, empirical evidence, critical issues. Theory \& Research in Social Education, 24(4), 331-359.

Yavari, Z., Kashtiaray, N., \& Ahmadi, G. (2013). Developing curriculum goals at the secondary level with an emphasis on citizenship education. Quarterly Journal of New Approach in Educational Management, 4(1), 147-166.

Ysseldyke, J., \& Olsen, K. (1999). Putting alternate assessments into practice: What to measure and possible sources of data. Exceptional Children, 65(2), 175-185. 